Vegetalika. 2018. 7(2): 16-29

\title{
Tanggapan Dua Kultivar Kedelai (Glycine max L.) terhadap Empat Aras Salinitas
}

\section{Response of Two Cultivars Soybean (Glycine max L.) to Four Salinity Levels}

\author{
Mahmud Ismail'1), Prapto Yudono ${ }^{\left.2^{*}\right)}$, Sriyanto Waluyo ${ }^{\left.2)^{*}\right)}$ \\ 1) Program Studi Agronomi, Fakultas Pertanian, Universitas Gadjah Mada \\ 2) Departemen Budidaya Pertanian, Fakultas Pertanian, Universitas Gadjah Mada \\ *) Penulis untuk korespondensi E-mail: sriyanto.waluyo@ugm.ac.id
}

\begin{abstract}
Salinity is one factor that can affect almost all soybean plant growths either vegetative or generative phases. The effect of saline on various varieties of soybean varies depending on the sensitivity of the variety. This study aims to determine the effect of giving four levels of saliniy on growth and yield of two varieties of soybean. The study used a completely randomized design with two factors (Factorial CRD). The first factor was Malika and Grobogan soybean varietiys. The second factor was salinity level: NO= control, $N_{1}=1,17 \mathrm{dS} / \mathrm{m}, N_{2}=2,34 \mathrm{dS} / \mathrm{m}$, and $N_{3}=3,51 \mathrm{dS} / \mathrm{m}$. The observed data were analyzed using variance analysis followed by Duncan Multiple Range Test (DMRT) with 95\% confidence level. The results showed that two varieties of soybean were able to survive under salinity level $1.17 \mathrm{dS} / \mathrm{m}$ variable plant height, root distribution, leaf area, root length on Malika variety, leaf fresh weight, leaf dry weight, number of pods per plant and total number per crop. Two varieties of soybean showed specification the highest decrease in yield under salinity level of $3.51 \mathrm{dS} / \mathrm{m}$. The yield decrease in Malika soybean varieties was $23 \%$ of pod number per plant, $31 \%$ seed number per crop, $39 \%$ dry weight of seed, and $20 \%$ of 100 seeds weight. While in Grobogan varieties was $18 \%$ pod number per plant, $17 \%$ seed number per crop, $26 \%$ dry seed weight, and $11 \% 100$ seeds weight.
\end{abstract}

Keywords: salinity, soybean, Malika, Grobogan

\section{INTISAR}

Salinitas merupakan salah satu faktor yang dapat mempengaruhi hampir semua pertumbuhan tanaman kedelai pada fase vegetatif dan generatif. Pengaruh salin pada berbagai varietas tanaman kedelai berbeda-beda tergantung pada tingkat kepekaan varietas tersebut. Penelitian ini bertujuan untuk mengetahui pengaruh pemberian empat kadar salin terhadap pertumbuhan dan hasil dua varietas kedelai. Penelitian menggunakan rancangan acak lengkap dengan dua faktor (CRD Faktorial) faktor pertama adalah varietas kedelai Grobogan dan varietas kedelai Malika. Faktor kedua adalah kadar salinitas: $\mathrm{N}_{0}=0 \mathrm{dS} / \mathrm{m}, \mathrm{N}_{1}=1,17 \mathrm{dS} / \mathrm{m}, \mathrm{N}_{2}=2,34 \mathrm{dS} / \mathrm{m}$, dan $\mathrm{N}_{3}=3,51 \mathrm{dS} / \mathrm{m}$. Data hasil pengamatan dianalisis menggunakan analisis varian dilanjutkan dengan uji jarak Duncan Multiple Range Test(DMRT) dengan tingkat kepercayaan 95\%. Hasil penelitian menunjukkan bahwa dua varietas kedelai mampu bertahan pada kadar salin $1,17 \mathrm{dS} / \mathrm{m}$ pengukuran variabel: tinggi tanaman, luas perakaran, luas daun, panjang akar 
pada varietas Malika, bobot segar daun, bobot kering daun, jumlah polong pertanaman dan jumlah biji pertanaman. Dua varietas kedelai menunjukkan penurunan hasil tertinggi pada pemberian kadar salin 3,51 dS/m. Penurunan hasil pada varietas kedelai Malika adalah 23\% jumlah polong pertanaman, 31\% jumlah biji pertanaman, 39\% berat kering biji , dan $20 \%$ berat 100 biji. Sedangkan pada varietas Grobogan terjadi penurunan $18 \%$ jumlah polong pertanaman, $17 \%$ jumlah biji pertanaman, $26 \%$ berat kering biji , dan $11 \%$ berat 100 biji.

Kata Kunci: salinitas, kedelai, Malika, Grobogan.

\section{PENDAHULUAN}

Produksi kedelai di Indonesia belum mampu memenuhi kebutuhan kedelai yang digunakan untuk berbagai kebutuhan, baik makanan tradisional, makanan olahan hingga bahan baku produk industri. Menurut Data Badan Pusat Statistik tahun 2015 produksi kedelai di Indonesia sebesar 963.099 ton, sedangkan kebutuhan kedelai nasional mencapai 2,23 juta ton. Banyaknya permintaan kedelai yang tidak diimbangi dengan pemenuhan kebutuhan kedelai akan berakibat pada kekurangan pasokan kedelai. Usaha yang dilakukan pemerintah saat ini untuk melakukan peningkatan produksi atau pemenuhan kebutuhan ialah dengan mengintensikan program penanaman padi, jagung dan kedelai (pajale). Usaha lain yang dapat dilakukan untuk memenuhi kebutuhan atau meningkatkan produktifitas pangan di Indonesia dengan melakukan beberapa usaha seperti teknik budidaya tanaman yang tepat dan usaha perluasan areal budidaya tanaman.

Tingginya pertumbuhan penduduk dan tingginya perluasan areal pemukiman penduduk mengakitbatkan terjadinya alih fungsi lahan pertanian subur menjadi areal pemukiman. Akibat dari alih fungsi lahan pertanian tersebut menyebabkan bergeser ke lahan-lahan yang kurang subur atau lahan-lahan marginal di berbagai tempat dengan akses yang baru. Lahan marginal di Indonesia sangatlah beragam mulai dari lahan hasil pertambangan yang telah ditinggalkan, lahan gambut, dan lahan pinggir pantai. Kegiatan budidaya terutama tanaman kedelai pada lahan marginal membutuhkan teknik budidaya yang tepat serta manajemen budidaya yang baik. Hal itu disebabkan dimana tanaman kedelai merupakan salah satu tanaman yang peka terhadap berbagai faktor permasalahan di lahan marginal tersebut.

Permasalahan lahan marginal salin yang ada di Indonesia dan banyak tersebar di beberapa tempat dapat mengakibatkan beberapa hal yang menyebabkan lahan tersebut menjadi salin, seperti pencemaran limbah rumah tangga, limbah industri, penguapan air yang mengangkat garam kepermukaan pada lahan terbuka, dan intrusi 
air laut. Tingkat salinitas di suatu lahan berbeda-beda tergantung tempat serta kondisi lingkungan di suatu lahan. Lahan salin yang ada akibat pencemaran limbah industri, lahan terbuka dan lahan di sepanjang 200 meter dari bibir pasir pantai dapat digunakan untuk kegiatan budidaya tanaman kedelai.

Keadaan tanaman pada lahan yang memiliki tingkat salinitas yang tinggi seperti $\mathrm{NaCl}$ akan membuat tanaman yang ditanam menghadapi beberapa kesulitan seperti kesulitan memperoleh air dari tanah karena adanya garam yang tinggi didalam tanah yang membuat perbedaan kadar di dalam tanah sehingga tanaman sulit. Kemudian kesulitan lainnya yang dihadapi tanaman pada tanaman dalam mengatasi garam tinggi adalah kadar ion tinggi $\mathrm{Na}^{+}$dan $\mathrm{Cl}^{-}$yang dapat menyebabkan racun bagi tanaman (Salisbury dan Ross, 1995). Pada awal perkecambahan tanaman salinitas dapat menurunkan daya kecambah benih tanaman kedelai hingga tidak mampu berkecambah pada kondisi salinitas lebih dari $7 \mathrm{dS} / \mathrm{m}$ (Mindari, et al., 2009).

Keadaan salin pada lahan budidaya akan berpengaruh terhadap pertumbuhan dan hasil tanaman. Respon tanaman terhadap salinitas akan ditunjukkan pada pertumbuhan yang terganggu serta hasil yang menurun dari keadaan normal. Menurut Ahmad Muharram, et al., (2011) pada awal pertumbuhan tanaman saat fase perkecambahan benih tanaman akan terhambat karena pengaruh salinitas, serta pertumbuhan yang tidak teratur pada tanaman pertanian. Menurut Rosmarkam dan Yuwono (2001) keadaan salin pada lahan tanaman budidaya pada tingkat salinitas 1\% hingga $3 \%$ akan membuat hasil produksi tanaman menurun. Kemudian produksi tanaman akan menurun drastis pada tingkat salinitas $3 \%$ hingga $5 \%$, dan pada tingkat salinitas lebih dari $10 \%$ akan membuat tanaman tidak dapat berproduksi sama sekali.

Pada dasarnya salinitas pada kosentrasi yang tinggi dapat mempengaruhi hampir semua fisiologis dan biokimia tanaman. Pengaruh salinitas tersebut mampu menurunkan pertumbuhan serta hasil tanaman tersebut (Darwish, et al. 2009). Namun demikian, kondisi tersebut masih dapat ditoleransi oleh tanaman pada batas-batas tertentu dimana setiap jenis tanaman memiliki batas-batas yang berbeda (Rabie dan Almadini, 2005).

Tanaman kedelai merupakan tanaman yang peka terhadap tingkat salinitas tertentu yang akan membuat pertumbuhan serta hasil produksi tanaman menjadi berkurang. Penelitian terhadap kepekaan tanaman kedelai terhadap salinitas telah dilakukan sebelumnya oleh Kristion, et al., (2013) bahwa terjadi penurunan hasil pada tanaman kedelai, kacang tanah, dan kacang hijau berturut-turut pada tingkat salinitas 5 $\mathrm{dS} / \mathrm{m}, 3,2 \mathrm{dS} / \mathrm{m}$, dan 1-2,65 dS/m. Penelitian lain yang dilakukan Khairunisa, et al.,( 
2004) membuktikan bahwa pada salinitas kadar $50 \mathrm{mM}$ mulai menunjukkan penurunan kualitas pertumbuhan tanaman kedelai varietas Jayawijaya sehingga kedelai varietas ini tergolong varietas yang sensitif terhadap kadar garam di atas $50 \mathrm{mM}$.

Penelitian kedelai di lahan salin pernah dilakukan oleh Balai Penelitian Tanaman Aneka Kacang dan Umbi (Balitkabi) pada tahun 2012 hingga 2013. Penelitian tersebut adalah pengujian toleransi beberapa genotipe kacang tanah, kacang hijau dan kedelai. Berdasarkan hal tersebut, perlu dilakukan penelitian lebih lanjut mengenai pengaruh kadar salinitas terhadap beberapa varietas tanaman lain terutama varietas kedelai.

\section{BAHAN DAN METODE}

Penelitian dilaksanakan di Kebun percobaan Tridarma Fakultas Pertanian Universitas Gadjah Mada, Banguntapan, Bantul, Yogyakarta. Sub-Laboratorium IImu Tanaman dan Sub-Laboratorium Ekologi Tanaman untuk kegiatan pengamatan tanaman sampel dan hasil tanaman. Penelitian dilaksanakan pada bulan Oktober 2016 hingga Desember 2016 dari awal penanaman hingga panen tanaman kedelai. Alat yang dibutuhkan pada penelitian meliputi lux meter, spektrometer, leaf area meter, timbangan analitik, alat pengukur panjang, labu takar, gelas ukur, beker gelas, botol plastik gelap, alat tulis, dan kamera digital. Bahan yang dibutuhkan pada penelitian meliputi $\mathrm{NaCl}$, benih kedelai varietas Malika dan varietas Grobogan, tanah, polybag ukuran $25 \times 25 \mathrm{~cm}$, pupuk kandang, pupuk Urea, TSP, dan KCL.

Penelitian menggunakan rancangan acak lengkap dengan dua faktor (CRD Faktorial). Faktor pertama adalah varietas yaitu varietas kedelai kuning (Grobogan) dan varietas kedelai hitam (Malika). Faktor kedua adalah kadar salinitas terdiri dari empat aras, yaitu $\mathrm{N}_{0}=$ kontrol, $\mathrm{N}_{1}=1,17 \mathrm{dS} / \mathrm{m}, \mathrm{N}_{2}=2,34 \mathrm{dS} / \mathrm{m}$, dan $\mathrm{N}_{3}=3,51 \mathrm{dS} / \mathrm{m}$. Tahap pelaksanaan penelitian dimulai dari persiapan benih, persiapan media tanam, penanaman, perlakuan pemberian kadar salinitas, perawatan, pengamatan dilapangan, pengambilan tanaman korban, dan panen.

Variabel penelitian yang diamati meliputi pengamatan variabel pertumbuhan (tinggi tanaman, panjang akar, luas perakaran, luas daun, bobot segar daun, bobot kering daun), dan pengamatan variabel komponen hasil (waktu berbunga, jumlah polong pertanaman, jumlah biji per polong, bobot kering biji, dan berat 100 biji). Data yang terkumpul dianalisis menggunakan analisis varian. Apabila perlakuan menunjukkan pengaruh yang nyata dilanjutkan dengan uji jarak Duncan Multiple Range Test (DMRT) dengan tingkat kepercayaan 95\%. 


\section{HASIL DAN PEMBAHASAN}

Tanaman kedelai merupakan salah satu tanaman jenis polong-polongan yang banyak ditanam diberbagai daerah pada berbagai jenis kondisi tanah. Salah satu kondisi tanah yang dapat mempengaruhi pertumbuhan serta hasil tanaman adalah kondisi tanah salin. Tanaman yang hidup di lahan salin akan menghadapi masalah utama yaitu dalam memperoleh air tanah yang memiliki potensial air lebih rendah sehingga dapat masuk kedalam jaringan tubuh tanaman dan mengatasi tingginya ion $\mathrm{Na}^{+}$dan $\mathrm{Cl}^{-}$(Salibury dan Ross, 1995). Salinitas mempengaruhi hampir semua aspek fisiologis dan biokimia pada tanaman sehingga menurunkan pertumbuhan dan hasil (Darwish, et al., 2009). Pengaruh salinitas terhadap pertumbuhan dan hasil tanaman kedelai dapat dilihat dari hasil penelitian dari beberapa variabel.

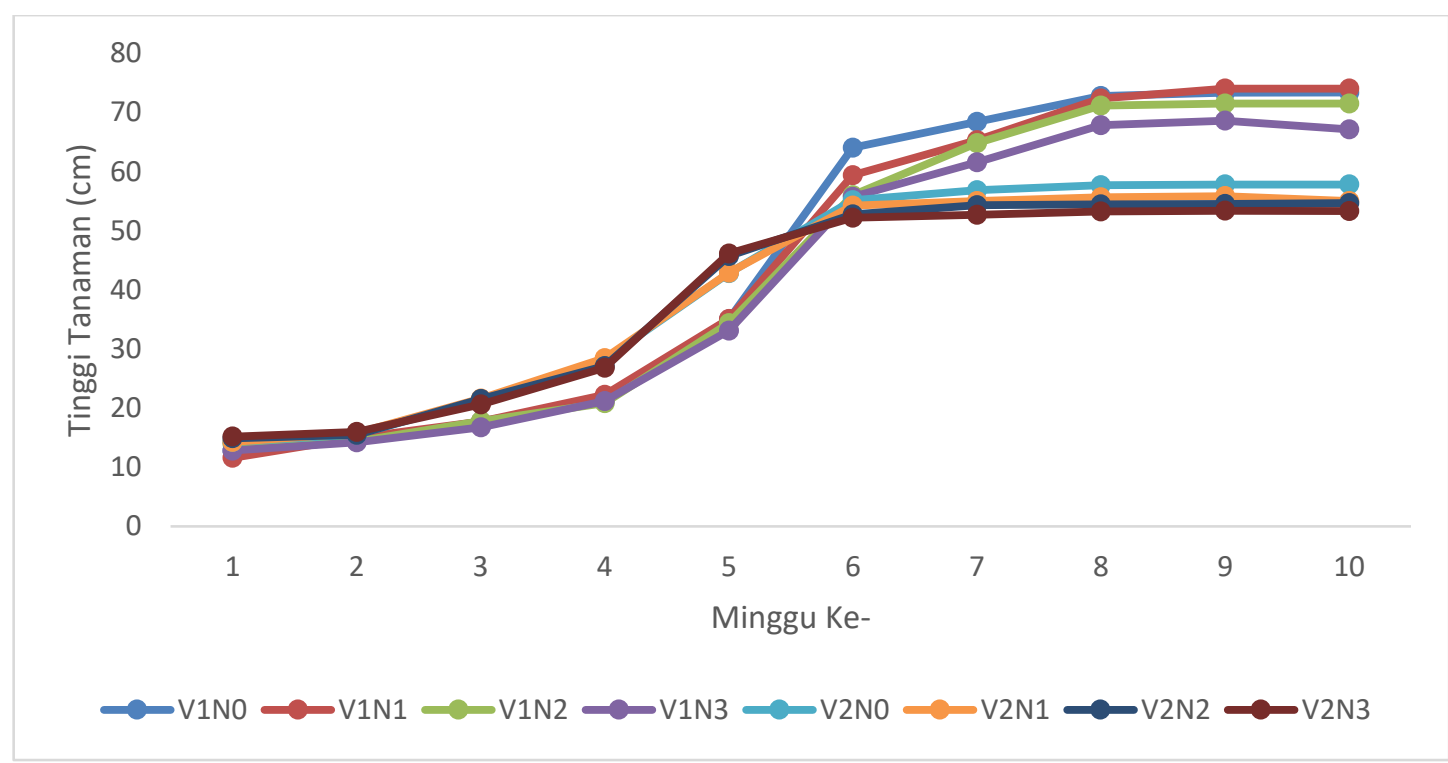

Gambar 1. Tinggi tanaman kedelai Malika dan Grobogan perminggu, V1= Malika, V2= Grobogan, $\mathrm{N} 0=0 \mathrm{dS} / \mathrm{m}, \mathrm{N} 1=1,17 \mathrm{dS} / \mathrm{m}, \mathrm{N} 2=2,34 \mathrm{dS} / \mathrm{m}$, dan N3=3,51 dS $/ \mathrm{m}$

Peningkatan kadar salin yang diberikan pada tanaman kedelai dapat menyebabkan pertumbuhan tinggi tanaman menurun karena ion $\mathrm{Na}^{+}$memiliki kemampuan untuk menukar ion $\mathrm{K}^{+}$didalam tanah sehingga jumlah ion $\mathrm{Na}^{+}$meningkat sedangkan $\mathrm{K}^{+}, \mathrm{Ca}^{2+}$ dan $\mathrm{Mg}^{2+}$ menurun (Amirjani, 2010). Peningkatan jumlah ion $\mathrm{Na}^{+}$ dalam tanah dan terserap oleh tanaman dalam jumlah yang berlebih yang terakumulasi pada vakuola dibandingkan pada sitoplasma dan apoplas akar sehingga menghambat distribusi $\mathrm{Na}^{+}$ke tajuk tanaman, dan membuat tanaman mengalami kerusakan pada tajuk yang lebih disebabkan akumulasi $\mathrm{Cl}^{-}$(Dabuxilatu dan Ikeda, 2005). Kerusakan pada tajuk tanaman dapat dilihat pada penurunan tinggi tanaman pada kadar salin lebih 
dari $2,34 \mathrm{dS} / \mathrm{m}$ dan $3,51 \mathrm{dS} / \mathrm{m}$ pada minggu ke-5 hingga minggu ke-10 meskipun penurunan tinggi tanaman tidak signifikan dan tidak menunjukkan pengaruh nyata.

Tabel 1. Panjang akar tanaman kedelai (cm)

\begin{tabular}{|c|c|c|c|c|c|}
\hline \multicolumn{6}{|c|}{4 minggu setelah tanam (mst) } \\
\hline \multirow{2}{*}{ Varietas } & \multicolumn{4}{|c|}{ Kadar salinitas (dS/m) } & \multirow{2}{*}{ Rerata } \\
\hline & 0 & 1,17 & 2,34 & 3,51 & \\
\hline Malika & $11,16 \mathrm{~cd}$ & $18,65 \mathrm{bcd}$ & $21,11 \mathrm{abcd}$ & $9,77 \mathrm{~d}$ & 15,17 \\
\hline Grobogan & $31,06 \mathrm{a}$ & $16,44 \mathrm{bcd}$ & $22,79 \mathrm{abc}$ & $24,28 a b$ & 23,64 \\
\hline Rerata & 21,11 & 17,55 & 21,95 & 17,07 & $(+)$ \\
\hline CV $(\%)$ & 33,47 & & & & \\
\hline \multicolumn{6}{|c|}{7 minggu setelah tanam (mst) } \\
\hline \multirow{2}{*}{ Varietas } & \multicolumn{4}{|c|}{ Kadar salinitas (dS/m) } & \multirow{2}{*}{ Rerata } \\
\hline & 0 & 1,17 & 2,34 & 3,51 & \\
\hline Malika & 19,4 & 19,35 & 13,45 & 17,04 & $17,30 \mathrm{a}$ \\
\hline Grobogan & 15,37 & 15,62 & 16,35 & 14,78 & $15,53 \mathrm{a}$ \\
\hline $\begin{array}{l}\text { Rerata } \\
\text { CV (\%) }\end{array}$ & $\begin{array}{c}17,38 \text { a } \\
29,92\end{array}$ & 17,49 a & $14,90 \mathrm{a}$ & $15,91 \mathrm{a}$ & $(-)$ \\
\hline \multicolumn{6}{|c|}{10 minggu setelah tanam (mst) } \\
\hline \multirow{2}{*}{ Varietas } & \multicolumn{4}{|c|}{ Kadar salinitas (dS/m) } & \multirow{2}{*}{ Rerata } \\
\hline & 0 & 1,17 & 2,34 & 3,51 & \\
\hline Malika & 23,47 & 23,41 & 16,25 & 20,62 & $20,94 \mathrm{a}$ \\
\hline Grobogan & 18,59 & 18,9 & 19,79 & 17,88 & $18,79 \mathrm{a}$ \\
\hline $\begin{array}{l}\text { Rerata } \\
\text { CV (\%) }\end{array}$ & $\begin{array}{c}21,03 \text { a } \\
29,93\end{array}$ & $21,16 \mathrm{a}$ & $18,02 \mathrm{a}$ & $19,25 \mathrm{a}$ & $(-)$ \\
\hline
\end{tabular}

Keterangan: Tanda (-) tidak ada interaksi (+) ada interaksi, Nilai yang diikuti huruf yang berbeda pada kolom yang sama menunjukkan ada beda nyata hasil uji DMRT taraf kepercayaan $95 \%$.

Akar merupakan salah satu organ tanaman yang sangat penting dimana akar berfungsi untuk mendapatkan air serta hara yang berada didalam tanah. Panjang akar pada tanaman menunjukkan kemampuan tanaman untuk mendapatkan air serta hara lebih dalam didalam tanah dengan masuk kedalam tanah lebih dalam kearah vertikal. Panjang akar dapat memberikan indikasi awal terhadap pengaruh perlakuan pemberian kadar salin. Peningkatan kadar salinitas $2,34 \mathrm{dS} / \mathrm{m}$ dan $3,51 \mathrm{dS} / \mathrm{m}$ pada tanaman tidak terjadi penurunan panjang akar tanaman kedelai pada umur 7 minggu setelah tanam dan 10 minggu setelah tanam berdasarkan analisis varian meskipun menunjukkan penurunan panjang akar. 
Mahmud Ismail et al., / Vegetalika. 2018. 7(2): 16-29

Tabel 2. Luas perakaran ( $\left.\mathrm{cm}^{2} / \operatorname{tanaman}\right)$

\begin{tabular}{|c|c|c|c|c|c|}
\hline \multicolumn{6}{|c|}{4 minggu setelah tanam (mst) } \\
\hline \multirow{2}{*}{ Varietas } & \multicolumn{4}{|c|}{ Kadar salinitas (dS/m) } & \multirow{2}{*}{ Rerata } \\
\hline & 0 & 1,17 & 2,34 & 3,51 & \\
\hline Malika & 169,98 & 110,91 & 99,71 & 57,81 & $109,60 \mathrm{~b}$ \\
\hline Grobogan & 133,87 & 107,73 & 99,77 & 117,53 & $114,73 \mathrm{a}$ \\
\hline $\begin{array}{l}\text { Rerata } \\
\text { CV (\%) }\end{array}$ & $\begin{array}{c}151,93 \mathrm{a} \\
26,95\end{array}$ & $109,32 \mathrm{~b}$ & $99,74 \mathrm{~b}$ & $87,67 \mathrm{~b}$ & $(-)$ \\
\hline \multicolumn{6}{|c|}{7 minggu setelah tanam (mst) } \\
\hline \multirow{2}{*}{ Varietas } & \multicolumn{4}{|c|}{ Kadar salinitas (dS/m) } & \multirow{2}{*}{ Rerata } \\
\hline & 0 & 1,17 & 2,34 & 3,51 & \\
\hline Malika & 242,23 & 265,24 & 159,8 & 157,32 & $206,15 \mathrm{a}$ \\
\hline Grobogan & 197,53 & 276,09 & 259,04 & 160,06 & $223,18 \mathrm{a}$ \\
\hline $\begin{array}{l}\text { Rerata } \\
\text { CV (\%) }\end{array}$ & $\begin{array}{c}219,88 \mathrm{ab} \\
34,56\end{array}$ & $270,66 \mathrm{a}$ & $209,42 a b$ & $158,69 \mathrm{~b}$ & $(-)$ \\
\hline \multicolumn{6}{|c|}{10 minggu setelah tanam (mst) } \\
\hline \multirow{2}{*}{ Varietas } & \multicolumn{4}{|c|}{ Kadar salinitas (dS/m) } & \multirow{2}{*}{ Rerata } \\
\hline & 0 & 1,17 & 2,34 & 3,51 & \\
\hline Malika & 278,56 & 305,03 & 183,76 & 180,91 & $237,07 \mathrm{a}$ \\
\hline Grobogan & 227,16 & 317,5 & 297,9 & 184,06 & $256,65 \mathrm{a}$ \\
\hline $\begin{array}{l}\text { Rerata } \\
\text { CV (\%) }\end{array}$ & $\begin{array}{c}252,86 \mathrm{ab} \\
34,58\end{array}$ & $311,26 \mathrm{a}$ & $240,83 a b$ & $182,49 \mathrm{~b}$ & $(-)$ \\
\hline
\end{tabular}

Keterangan: Tanda (-) tidak ada interaksi. Nilai yang diikuti huruf yang berbeda pada kolom yang sama menunjukkan ada beda nyata hasil uji DMRT taraf kepercayaan 95\%.

Peningkatan kadar salinitas dapat mengganggu serapan hara oleh tanaman. Perlakuan kadar salin 1,17dS/m, 2,34 dS/m dan 3,51 dS/m pada umur 4 minggu setelah tanam dapat menurunkan luas perakaran pada tanaman kedelai dibandingkan perlakuan control. Peningkatan kadar salin akan menyebabkan terganggunya serapan hara karena tingginya kadar salinitas pada tanaman yang menyababkan terjadinya penurunan jumlah unsur hara $\mathrm{K}^{+}$akibat tingginya unsur $\mathrm{Na}^{+}$dimedia tempat tumbuh tanaman. Unsur hara $\mathrm{K}^{+}$bagi tanaman sangat penting karena berperan dalam perkembangan akar tanaman kedelai (BBPP-Lembang, 2014). Peningkatan kadar salin yang tinggi menyebabkan penurunan yang nyata terhadap luas akar tanaman yang dapat menyebabkan penurunan jumlah serapan hara dalam tanah sehingga akan berakibat pada penurunan suplai hara dari akar ke tajuk dan daun. Penurunan suplai unsur hara tersebut akan mengakibatkan terganggunya proses fotosintesis tanaman yang berimbas pada penurunan berat segar dan berat kering tanaman. 
Tabel 3. Luas daun tanaman kedelai ( $\mathrm{cm}^{2} /$ tanaman)

\begin{tabular}{|c|c|c|c|c|c|}
\hline \multicolumn{6}{|c|}{4 minggu setelah tanam (mst) } \\
\hline \multirow{2}{*}{ Varietas } & \multicolumn{4}{|c|}{ Kadar salinitas (dS/m) } & \multirow{2}{*}{ Rerata } \\
\hline & 0 & 1,17 & 2,34 & 3,51 & \\
\hline Malika & 14,81 & 13,56 & 11,8 & 10,93 & $12,77 \mathrm{~b}$ \\
\hline Grobogan & 21,42 & 20,87 & 13,63 & 15,53 & $17,87 \mathrm{a}$ \\
\hline Rerata & $18,12 \mathrm{a}$ & $17,22 \mathrm{a}$ & $12,72 \mathrm{a}$ & $13,23 \mathrm{a}$ & $(-)$ \\
\hline CV (\%) & 30,56 & & & & \\
\hline \multicolumn{6}{|c|}{7 minggu setelah tanam (mst) } \\
\hline \multirow{2}{*}{ Varietas } & \multicolumn{4}{|c|}{ Kadar salinitas (dS/m) } & \multirow{2}{*}{ Rerata } \\
\hline & 0 & 1,17 & 2,34 & 3,51 & \\
\hline Malika & $32,46 \mathrm{~b}$ & $42,56 \mathrm{a}$ & $21,72 \mathrm{c}$ & $20,14 \mathrm{c}$ & 29,22 \\
\hline Grobogan & $21,57 \mathrm{c}$ & $22,54 \mathrm{c}$ & $17,58 \mathrm{c}$ & $14,23 \mathrm{c}$ & 18,98 \\
\hline Rerata & 27,01 & 32,55 & 19,65 & 17,19 & $(+)$ \\
\hline CV (\%) & 19,35 & & & & \\
\hline \multicolumn{6}{|c|}{10 minggu setelah tanam (mst) } \\
\hline \multirow{2}{*}{ Varietas } & \multicolumn{4}{|c|}{ Kadar salinitas (dS/m) } & \multirow{2}{*}{ Rerata } \\
\hline & 0 & 1,17 & 2,34 & 3,51 & \\
\hline Malika & $15,86 \mathrm{a}$ & $5,02 \mathrm{c}$ & $0,98 \mathrm{~d}$ & $0,00 \mathrm{~d}$ & 5,46 \\
\hline Grobogan & $9,05 \mathrm{~b}$ & $5,38 \mathrm{c}$ & $0,00 \mathrm{~d}$ & $0,00 \mathrm{~d}$ & 3,61 \\
\hline Rerata & 12,45 & 5,2 & 0,49 & 0 & $(+)$ \\
\hline CV (\%) & 37,23 & & & & \\
\hline
\end{tabular}

Keterangan: Tanda (-) tidak ada interaksi (+) ada interaksi, Nilai yang diikuti huruf yang berbeda pada kolom yang sama menunjukkan ada beda nyata hasil uji DMRT taraf kepercayaan $95 \%$.
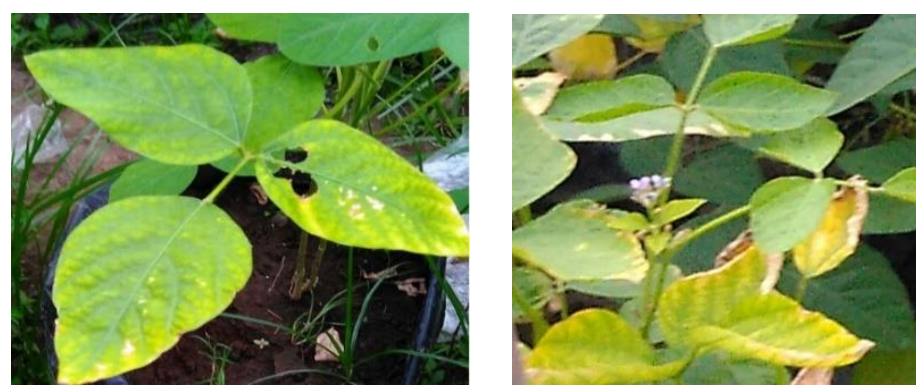

Gambar 2. Kondisi daun akibat salinitas

Peningkatan kadar salinitas secara berturut-turut pada tanaman kedelai akan direspon tanaman dengan menurunkan luas daun dengan mengecilkan luas daun. Penurunan luas daun pada tanaman kedelai merupakan salah satu bentuk mekanisme tanaman terhadap kondisi salin pada tanah dimana mekanisme untuk menekan kehilangan air akibat proses respirsi tersebut adalah mekanisme morfologi. Pada umur 10 minggu setelah tanam penurunan luas daun terlihat jelas dimana pada perlakuan $2,34 \mathrm{dS} / \mathrm{m}$ dan $3,51 \mathrm{dS} / \mathrm{m}$ pada varietas grobogan dan pada pelakuan $3,51 \mathrm{dS} / \mathrm{m}$ terjadi kerontokan dini seluruh daun pada kedua varietas tanaman kedelai. Selain penurunan luas daun tanaman kedelai, salinitas memberikan pengaruh pada penurunan kadar Klorofil pada daun tanaman. Penurunan kandungan klorofil dalam daun diakibatkan 
pada penurunan serapan unsur hara $\mathrm{Mg}^{2+}$ yang berperan sebagai pembentukan klorofil pada daun tanaman dan akumulasi $\mathrm{Cl}^{-}$yang membuat tanaman menjadi klorosis.

Tabel 4. Waktu berbunga (hari)

\begin{tabular}{|c|c|c|c|c|c|}
\hline \multirow{2}{*}{ Varietas } & \multicolumn{4}{|c|}{ Kadar salinitas (dS/m) } & \multirow[t]{2}{*}{ Rerata } \\
\hline & 0 & 1,17 & 2,34 & 3,51 & \\
\hline Malika & $35,33 \mathrm{a}$ & $32,67 b$ & $30,67 b$ & $27,67 d$ & 31,58 \\
\hline Grobogan & $30,67 \mathrm{~b}$ & $31,00 \mathrm{~b}$ & $28,33 \mathrm{c}$ & $27,67 \mathrm{~cd}$ & 29,08 \\
\hline $\begin{array}{l}\text { Rerata } \\
\text { CV (\%) }\end{array}$ & $\begin{array}{c}32 \\
2,23\end{array}$ & 31,17 & 29,5 & 27,67 & $(+)$ \\
\hline
\end{tabular}

Keterangan: Tanda (+) ada interaksi, Nilai yang diikuti huruf yang berbeda pada kolom yang sama menunjukkan ada beda nyata hasil uji DMRT taraf kepercayaan 95\%.

Peningkatan pemberian kadar salinitas pada tanaman secara tidak langsung akan merangsang tanaman dan direspon dengan memunculkan bunga lebih cepat dari waktunya. Hal tersebut dikarenakan pemberian $\mathrm{NaCl}$ pada tanaman akan membuat tanaman dalam keadaan tercekam air dan keracunan oleh ion $\mathrm{Cl}^{-}$.

Tabel 5. Bobot segar daun tanaman kedelai (gram/tanaman)

\begin{tabular}{|c|c|c|c|c|c|}
\hline \multicolumn{6}{|c|}{4 minggu setelah tanam (mst) } \\
\hline \multirow{2}{*}{ Varietas } & \multicolumn{4}{|c|}{ Kadar salinitas (dS/m) } & \multirow[t]{2}{*}{ Rerata } \\
\hline & 0 & 1,17 & 2,34 & 3,51 & \\
\hline Malika & $17,20 \mathrm{a}$ & $15,58 a b$ & $16,79 \mathrm{a}$ & $11,14 \mathrm{bc}$ & 15,18 \\
\hline Grobogan & $14,83 \mathrm{ab}$ & $13,23 \mathrm{abc}$ & $11,75 \mathrm{bc}$ & $9,75 \mathrm{c}$ & 12,39 \\
\hline $\begin{array}{l}\text { Rerata } \\
\text { CV (\%) }\end{array}$ & $\begin{array}{c}16,02 \\
18,7\end{array}$ & 14,41 & 14,27 & 10,45 & $(+)$ \\
\hline \multicolumn{6}{|c|}{7 minggu setelah tanam (mst) } \\
\hline \multirow{2}{*}{ Varietas } & \multicolumn{4}{|c|}{ Kadar salinitas (dS/m) } & \multirow[t]{2}{*}{ Rerata } \\
\hline & 0 & 1,17 & 2,34 & 3,51 & \\
\hline Malika & 57,74 & 69,08 & 39,35 & 37,48 & $50,91 \mathrm{a}$ \\
\hline Grobogan & 37,11 & 37,98 & 30,45 & 23,6 & $32,29 \mathrm{~b}$ \\
\hline $\begin{array}{l}\text { Rerata } \\
\text { CV (\%) }\end{array}$ & $\begin{array}{c}47,42 \mathrm{a} \\
19,15\end{array}$ & $53,53 \mathrm{a}$ & $34,90 \mathrm{~b}$ & $30,54 \mathrm{~b}$ & $(-)$ \\
\hline \multicolumn{6}{|c|}{10 minggu setelah tanam (mst) } \\
\hline \multirow{2}{*}{ Varietas } & \multicolumn{4}{|c|}{ Kadar salinitas (dS/m) } & \multirow[t]{2}{*}{ Rerata } \\
\hline & 0 & 1,17 & 2,34 & 3,51 & \\
\hline Malika & $29,05 \mathrm{a}$ & $5,98 \mathrm{c}$ & $1,31 d$ & $0,00 \mathrm{~d}$ & 9,08 \\
\hline Grobogan & $14,87 \mathrm{~b}$ & $3,37 \mathrm{~cd}$ & $0,00 \mathrm{~d}$ & $0,00 \mathrm{~d}$ & 4,56 \\
\hline Rerata & 21,96 & 4,67 & 0,66 & 0 & $(+)$ \\
\hline CV (\%) & 31,63 & & & & \\
\hline
\end{tabular}

Keterangan: Tanda (-) tidak ada interaksi (+) ada interaksi, Nilai yang diikuti huruf yang berbeda pada kolom yang sama menunjukkan ada beda nyata hasil uji DMRT taraf kepercayaan $95 \%$.

Penurunan kadar klorofil dalam daun akan mempengaruhi tanaman dalam proses fotosintesis untuk menghasilkan bahan kering yang disimpan didalam akar, tajuk dan daun tanaman. Penurunan bobot segar paling terlihat pada daun tanaman kedelai pada pemberian kadar salinitas 2,34 dS/m dan 3,51 dS/m dapat menurunkan bobot segar daun secara nyata pada tanaman secara berturut-turut terutama pada umur 10 minggu setelah tanam dimana daun mengalami kerontokan dini. Penurunan bobot segar 
pada daun tanaman kedua varietas yang diuji pula mempengaruhi bobot kering yang dihasilkan tanaman dalam daun tanaman seperti dapat dilihat pada tabel berikut:

Tabel 6. Bobot kering daun tanaman kedelai (gram/tanaman)

\begin{tabular}{|c|c|c|c|c|c|}
\hline \multicolumn{6}{|c|}{4 minggu setelah tanam (mst) } \\
\hline \multirow{2}{*}{ Varietas } & \multicolumn{4}{|c|}{ Kadar salinitas (dS/m) } & \multirow{2}{*}{ Rerata } \\
\hline & 0 & 1,17 & 2,34 & 3,51 & \\
\hline Malika & 4,10 & 3,64 & 3,83 & 2,60 & $3,54 a$ \\
\hline Grobogan & 3,51 & 3,20 & 2,46 & 2,42 & $2,90 \mathrm{a}$ \\
\hline $\begin{array}{l}\text { Rerata } \\
\text { CV (\%) }\end{array}$ & $\begin{array}{l}3,81 \mathrm{a} \\
23,14\end{array}$ & $3,42 a b$ & $3,14 a b$ & $2,51 \mathrm{~b}$ & $(-)$ \\
\hline \multicolumn{6}{|c|}{7 minggu setelah tanam (mst) } \\
\hline \multirow{2}{*}{ Varietas } & \multicolumn{4}{|c|}{ Kadar salinitas (dS/m) } & \multirow{2}{*}{ Rerata } \\
\hline & 0 & 1,17 & 2,34 & 3,51 & \\
\hline Malika & 13,79 & 12,50 & 7,98 & 8,16 & $10,61 \mathrm{a}$ \\
\hline Grobogan & 9,11 & 8,87 & 7,15 & 5,44 & $7,64 \mathrm{~b}$ \\
\hline $\begin{array}{l}\text { Rerata } \\
\text { CV (\%) }\end{array}$ & $\begin{array}{c}11,45 \mathrm{a} \\
18,37\end{array}$ & $10,69 \mathrm{a}$ & $7,56 \mathrm{~b}$ & $6,80 \mathrm{~b}$ & $(-)$ \\
\hline \multicolumn{6}{|c|}{10 minggu setelah tanam $(\mathrm{mst})$} \\
\hline \multirow{2}{*}{ Varietas } & \multicolumn{4}{|c|}{ Kadar salinitas (dS/m) } & \multirow{2}{*}{ Rerata } \\
\hline & 0 & 1,17 & 2,34 & 3,51 & \\
\hline Malika & $9,06 \mathrm{a}$ & $3,01 \mathrm{bc}$ & $1,45 \mathrm{~cd}$ & $0,00 \mathrm{~d}$ & 3,38 \\
\hline Grobogan & $4,36 \mathrm{~b}$ & $1,27 d$ & $0,00 \mathrm{~d}$ & $0,00 \mathrm{~d}$ & 1,41 \\
\hline Rerata & 6,71 & 2,14 & 0,73 & 0 & $(+)$ \\
\hline $\mathrm{CV}(\%)$ & 38,91 & & & & \\
\hline
\end{tabular}

Keterangan: Tanda (-) tidak ada interaksi (+) ada interaksi, Nilai yang diikuti huruf yang berbeda pada kolom yang sama menunjukkan ada beda nyata hasil uji DMRT taraf kepercayaan $95 \%$.

Peningkatan kadar salinitas pada tanaman kedelai akan menyebabkan terganggunya proses fotosintesis dalam daun untuk pembentukan asimilat dan penimbunan hasil fotosintesis tanaman. Pemberian kadar salinitas $3,51 \mathrm{dS} / \mathrm{m}$ akan berdampak pada penurunan jumlah kadar klorofil yang sangat penting untuk proses fotosinteris dalam menghasilkan biomassa(bahan kering) tanaman yang disimpan didalam seluruh bagian tumbuhan seperti daun, tajuk, dan akar tanaman kedelai. Penurunan bobot kering daun atau daun tanaman akan mengalami kerontokan dini pada stadia pengisian polong tanaman dapat dilihat pada pengamatan 10 mst seperti gambar berikut: 


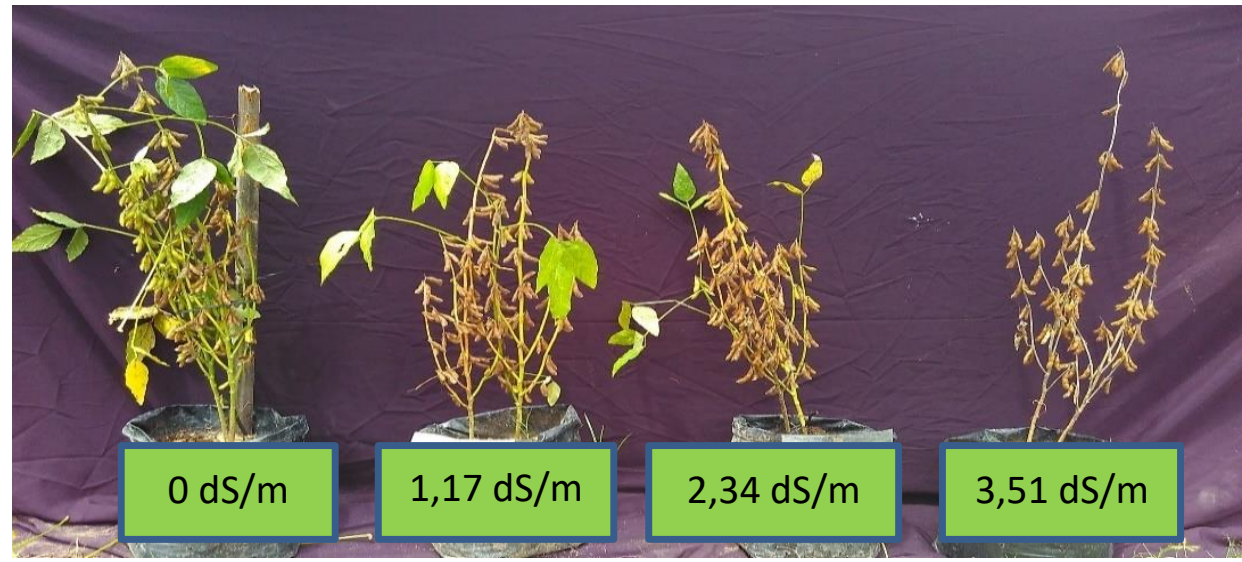

Gambar 3. Kondisi Tanaman Kedelai Varietas Malika Umur 10mst

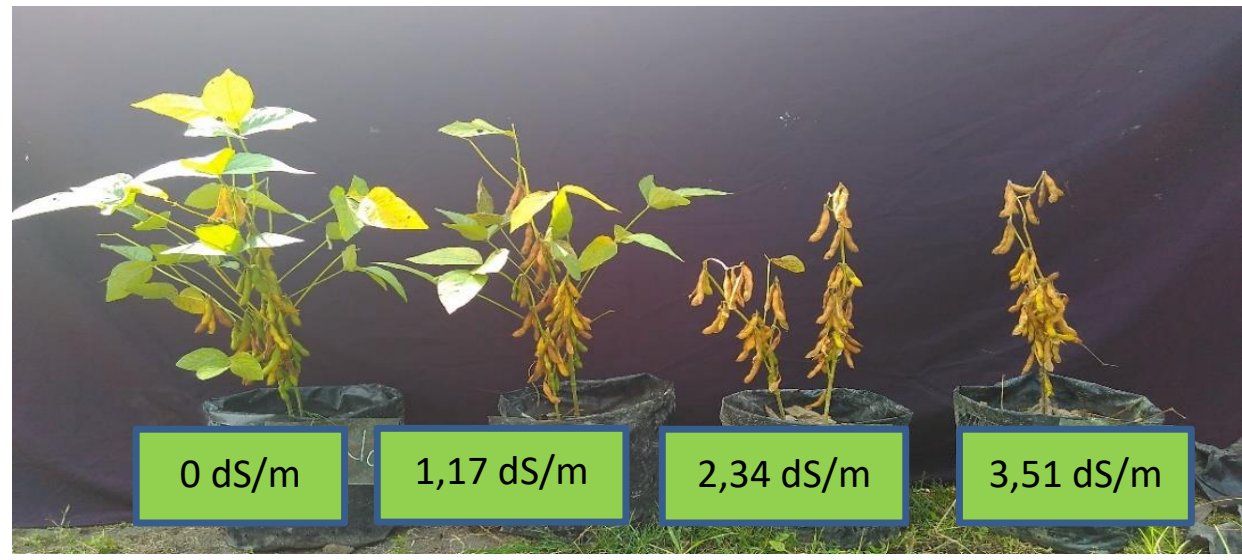

Gambar 4. Kondisi Tanaman Kedelai Varietas Grobogan Umur 10mst

Berdasarkan hasil penelitian dapat dilihat pada Gambar 3 dan Gambar 4 bahwa pemberian kadar salinitas secara berturut-turut memberikan pengaruh secara nyata pada penampakan fisiologis tanaman dimana daun mengalami kerontokan dini pada pemberian kadar salinitas $1,17 \mathrm{dS} / \mathrm{m}, 2,34 \mathrm{dS} / \mathrm{m}$ dan $3,51 \mathrm{dS} / \mathrm{m}$. Penelitian yang dilakukan Ghassemi-Golezani et al., (2011) menyatakan bahwa daun pada tanaman yang di berikan perlakuan salinitas akan cepat mengalami kerontokan dini (senescence) akibat dari pemberian salinitas $(\mathrm{NaCl})$. 
Tabel 7. Komponen hasil tanaman kedelai

\begin{tabular}{|c|c|c|c|c|c|}
\hline \multicolumn{6}{|c|}{ Jumlah polong pertanaman } \\
\hline \multirow{2}{*}{ Varietas } & \multicolumn{4}{|c|}{ Kadar salinitas (dS/m) } & \multirow{2}{*}{ Rerata } \\
\hline & 0 & 1,17 & 2,34 & 3,51 & \\
\hline Malika & $156,33 \mathrm{a}$ & $158,00 \mathrm{a}$ & $153,00 \mathrm{a}$ & $120,00 \mathrm{~b}$ & 146,83 \\
\hline Grobogan & $77,67 \mathrm{c}$ & $75,33 \mathrm{c}$ & $66,67 \mathrm{c}$ & $63,33 \mathrm{c}$ & 70,75 \\
\hline Rerata & 117,00 & 116,67 & 109,83 & 91,67 & $(+)$ \\
\hline CV (\%) & 7,39 & & & & \\
\hline \multicolumn{6}{|c|}{ Jumlah biji pertanaman } \\
\hline \multirow{2}{*}{ Varietas } & \multicolumn{4}{|c|}{ Kadar salinitas (dS/m) } & \multirow{2}{*}{ Rerata } \\
\hline & 0 & 1,17 & 2,34 & 3,51 & \\
\hline Malika & $301,67 \mathrm{a}$ & $301,33 a b$ & $278,00 \mathrm{~b}$ & 206,67 c & 271,92 \\
\hline Grobogan & $153,67 d$ & $141,00 \mathrm{~d}$ & $127,67 d$ & $127,67 \mathrm{~d}$ & 137,5 \\
\hline Rerata & 227,67 & 221,17 & 202,83 & 167,17 & $(+)$ \\
\hline CV (\%) & 7,09 & & & & \\
\hline \multicolumn{6}{|c|}{ Berat kering biji (gram/tanaman) } \\
\hline \multirow{2}{*}{ Varietas } & \multicolumn{4}{|c|}{ Kadar salinitas $(\mathrm{dS} / \mathrm{m})$} & \multirow{2}{*}{ Rerata } \\
\hline & 0 & 1,17 & 2,34 & 3,51 & \\
\hline Malika & 35,90 & 34,93 & 30,82 & 21,60 & $30,82 a$ \\
\hline Grobogan & 29,77 & 27,13 & 23,49 & 22,07 & $25,62 b$ \\
\hline Rerata & $32,85 \mathrm{a}$ & $31,03 a b$ & $27,16 \mathrm{~b}$ & $21,84 \mathrm{c}$ & $(-)$ \\
\hline CV (\%) & 10,85 & & & & \\
\hline \multicolumn{6}{|c|}{ Berat 100 biji (gram/tanaman) } \\
\hline \multirow{2}{*}{ Varietas } & \multicolumn{4}{|c|}{ Kadar salinitas (dS/m) } & \multirow{2}{*}{ Rerata } \\
\hline & 0 & 1,17 & 2,34 & 3,51 & \\
\hline Malika & 9,50 & 9,09 & 8,79 & 8,13 & $8,88 \mathrm{~b}$ \\
\hline Grobogan & 19,38 & 18,63 & 17,95 & 16,56 & $18,13 a$ \\
\hline Rerata & $14,44 a$ & $13,86 a b$ & $13,37 \mathrm{~b}$ & $12,35 \mathrm{c}$ & $(-)$ \\
\hline CV (\%) & 4,73 & & & & \\
\hline
\end{tabular}

Keterangan: Tanda (-) tidak ada interaksi (+) ada interaksi, Nilai yang diikuti huruf yang berbeda pada kolom yang sama menunjukkan ada beda nyata hasil uji DMRT taraf kepercayaan $95 \%$.

Pemberian kadar salinitas selain mempengaruhi pertumbuhan tanaman mempengaruhi komponen hasil dimana hasil tanaman kedelai varietas Malika dan Grobogan dapat menurun pada pemberian kadar salinitas 2,34 dS/m dan 3,51 dS/m. Penurunan hasil pada pemberian kadar salinitas $2,34 \mathrm{dS} / \mathrm{m}$ terjadi pada berat kering biji dan berat 100 biji dua varietas namun penurunan hasil pada semua komponen hasil tertinggi pada pemberian kadar salinitas 3,51 dS/m menurunkan sekitar $23 \%$ jumlah polong pertanaman, 31\% jumlah biji pertanaman, 39\% berat kering biji, dan $20 \%$ berat 100 biji. Sedangkan penurunan hasil pada varietas Grobogan adalah $18 \%$ jumlah polong pertanaman, $17 \%$ jumlah biji pertanaman, $26 \%$ berat kering biji , dan $11 \%$ berat 100 biji. 
Pemberian kadar salinitas pada tanaman tidak semua menurunkan semua variabel pengamatan. Tanaman kedelai varietas Malika dan Grobogan mampu bertahan pada perlakuan kadar salin 1,17 dS/m dapat dilihat pada variabel tinggi tanaman, panjang akar, luas akar tanaman, luas daun, waktu berbunga pada varietas Grobogan, bobot segar dan bobot kering daun umur 4 dan 7 minggu setelah tanam, jumlah polong pertanaman dan jumlah biji pertanaman.

\section{KESIMPULAN}

1. Dua varietas kedelai mampu bertahan dari kerusakan pada kadar salin $1,17 \mathrm{dS} / \mathrm{m}$ pada pengukuran variabel tinggi tanaman, panjang akar, luas akar tanaman, luas daun, waktu berbunga pada varietas Grobogan, bobot segar dan bobot kering daun umur 4 dan 7 minggu setelah tanam, jumlah polong pertanaman dan jumlah biji pertanaman.

2. Kadar salin $3,51 \mathrm{dS} / \mathrm{m}$ menurunkan hasil tanaman cukup sigifikan pada semua komponen hasil. Penurunan komponen hasil seperti jumlah polong pertanaman, jumlah biji pertanaman, berat kering biji, berat 100 biji berturut-turut pada varietas Malika sebesar $23 \%$ jumlah polong pertanaman, 31\% jumlah biji pertanaman, 39\% berat kering biji, dan $20 \%$ berat 100 biji. Sedangkan varietas Grobogan terjadi penurunan sebesar $18 \%$ jumlah polong pertanaman, $17 \%$ jumlah biji pertanaman, $26 \%$ berat kering biji, dan $11 \%$ berat 100 biji.

\section{SARAN}

Penelitian mengenai pemberian larutan garam $(\mathrm{NaCl})$ pada tanaman kedelai perlu dilanjutkan dengan menggunakan varietas lainya atau dengan penambahan bahan tertentu sehingga diperoleh informasi tambahan mengenai varietas yang mampu bertahan dari kerusakan pada kondisi salinitas tertentu dan manfaat $\mathrm{NaCl}$ seperti mempercepat panen dengan menekan kerugian akibat pengaruh $\mathrm{NaCl}$ berlebihan.

\section{DAFTAR PUSTAKA}

Alshamary, S.F.,Y.L. Qian andS. J. Wallner. 2004. Growth responseof four turfgrass species to salinity. Agr. Water Manag. 66:97-111.

Amirjani, M.R. 2010. Effect of Salinity Stress on Growth, Mineral Composition, Proline Content, Antioxidant Enzymes of Soybean. Am. J. of Plant Physiol. 5:350-360.

An, P., S. Inanaga, Y.Cohen,U. Kafkafi, and Y. Sugimoto. 2002. Salt tolerance in two soybean cultirvars, J. Plant Nutrn. 25:407-423. 
Balitkabi. 2013. Toleransi kacang tanah, kacang hijau, dan kedelai terhadap salinitas. http://balitkabi.litbang.pertanian.go.id/?p=3122. Diakses 2 januari 2018

BBPP-Lembang, 2014. Peran Unsur Hara Kalium (K) Bagi Tanaman. http://www.bbpplembang.info/index.php/arsip/artikel/artikel-pertanian/833-peran-unsur-harakalium-k-bagi-tanaman. Diakses 1 Januari 2018.

BPS. 2015. http://www.bps.go.id/linkTableDinamis/view/id/871. Diakses 2 januari 2018.

Dabuxilatu and M. Ikeda. 2005. Distribution of K, Na and C1 in Root and Leaf Cells of Soybean and Cucumber Plants Grown under Salinity Conditions. Soil Sci. Plant Nutr. 51(7):1053-1057.

Darwish, E., C. Testerink, M. Khalil, O. El-Shihy and T. Munnik. 2009. Phospholipid signaling responses in salt-stressed rice leaves. Plant Cell Physiol. 50(5):986997.

Ghassemi-Golezani, K., M. Taifeh-Noori, S. Oustan, M. Moghaddam and S. S. Rahmani. 2011. Pwihysiological Performance of Soybean Cultivars Under Salinity Stress. J. of Plant Physiol. and Breeding 1(1):1-7.

Khairunisa, R. Yuniali, dan L. S. Nurusman. 2004. Pengaruh salinitas terhadap pertumbuhan kedelai (Glycine max (L.)Merr) varietas Jayawijaya. Universitas Indonesia.

Kristiono,A., R. D. Purwaningrahayu, A. Taufiq.2013. Respon Tanaman Kedelai, Kacang Tanah, dan Kacang Hijau Terhadap Cekaman Salinitas. Balai Penelitian Tanaman Aneka Kacang dan Umbi.

Mindari, W., Maroeto, dan Syekhfani. 2009. Ameliorasi Air salin menggunakan pupuk organik untuk meningkatkan produksi tanaman kedelai dan jagung dalam rotasi. Penelitian Hibah Bersaing DP2M Dikti TA. 2009. 37 hlm.

Muharram, A., A. Qadir, dan Suwarno. 2011. Pengujian Toleransi Padi (Oryza sativa L.) Terhadap Salinitas Pada Fase Perkecambahan. Institut Pertanian Bogor.

Rabie G.H., A.M. Almadini. 2005. Role of bioinoculants in development of salttolerance of Vicia faba plants under salinity stress. Afr. J. of Biotech. 4 (3):210222.

Rosmarkam, A dan N.M Yuwono. 2001. Ilmu Kesuburan Tanah. Penerbit Kanisius. Yogyakarta.

Salibury, F.B. and C.W. Ross. 1995. Fisiologi Tumbuhan. Penerbit ITB, Bandung. 